\title{
Organometallic Chemistry in Non-Classical Environments
}

\author{
Paul J. Dyson*
}

\begin{abstract}
A summary of our on-going research on organometallic chemistry is provided with an emphasis on the function, reactivity and mechanisms of organometallic compounds in water, ionic liquids and in living systems. The role of organometallic compounds in both catalysis and medicinal chemistry are briefly described.
\end{abstract}

Keywords: Biphasic catalysis · Bioorganometallic chemistry · Catalysis · Organometallic chemistry · Reaction mechanisms

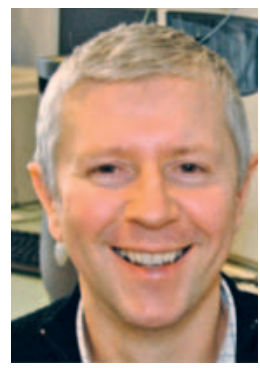

Organometallic chemistry is a fascinating subject of immense academic curiosity that is also of considerable importance to the well-being of the chemical and pharmaceutical industries. Our research on organometallic chemistry includes a major component of what can be viewed as more traditional mechanistic studies, synthesis and catalysis, but in addition to this research, organometallic chemistry in nontraditional environments also represents a major interest of my laboratory. The two main aspects of this so-called, organometallic chemistry in 'non-classical' environments, have already been briefly reviewed in CHIMIA, with an article on biphasic catalysis using ionic liquids based on my Werner Prize Lecture in 2004[1] and the second article appearing in a special issue on the biological role of metal compounds in 2007[2] edited by Roger Alberto from the University of Zürich.
Irrespective of the context of the problem under study the scientific approach taken shares common characteristics, comprising fundamental mechanistic studies, followed by the synthesis of new compounds to test hypotheses, which ultimately leads to compounds that exhibit superior properties in given applications. As an illustration of this approach, we investigated the mechanism of the reaction, $\left[\mathrm{Ru}\left(\eta^{6}-\mathrm{p}\right.\right.$-cymene $)\left(\eta^{1}-(\mathrm{P}-\mathrm{P}) \mathrm{Cl}_{2}\right] \rightarrow$ $\left[\mathrm{Ru}\left(\eta^{6}\right.\right.$-p-cymene $)\left(\eta^{2}-(\mathrm{P}-\mathrm{P}) \mathrm{Cl}\right]^{+},{ }^{[3]}$ finding that a concerted substitution is in operation, whereas the related reaction, $\left[\mathrm{Ru}\left(\eta^{6}{ }_{-}\right.\right.$ $\mathrm{p}$-cymene $)\left(\eta^{1}-(\mathrm{P}-\mathrm{P})\left(\mathrm{PPh}_{3}\right) \mathrm{Cl}\right]^{+} \rightarrow\left[\mathrm{Ru}\left(\eta^{6}-\right.\right.$ $\mathrm{p}$-cymene $)\left(\eta^{2}-(\mathrm{P}-\mathrm{P}) \mathrm{Cl}\right]^{+}$, occurs via a dissociative mechanism. Since related compounds have useful catalytic properties, ${ }^{[4]}$ we hypothesised that these bis-phosphine ruthenium(II)-arene complexes might be efficient hydrogenation catalysts, and subsequent studies including catalyst optimisation resulted in the discovery of a highly active compound for the chemoselective hydrogenation of $\mathrm{C}=\mathrm{O}$ bonds in the presence of $\mathrm{C}=\mathrm{C}$ bonds using molecular hydrogen (see Fig. 1). ${ }^{[5]}$
The mechanismby which ruthenium(II)arene compounds catalyse hydrogenation reactions depends on the nature of the coligands, the counter anion, the substrate and even the solvent. Electronically unsaturated ruthenium(II)-arene compounds with sterically demanding $\beta$-diketonate ligands activate hydrogen across the metal-ligand frame to give a metal hydride ligand and an organic hydrogen atom (Fig. 2). ${ }^{6]}$ These compounds are highly active catalysts for regioselective hydrogenation of $\mathrm{C}=\mathrm{C}$ bonds, ${ }^{[7]}$ and weakly coordinating counter-anions, often used to facilitate catalytic reactions, ${ }^{[8]}$ suppress their activity due to ion-pairing with the active catalyst species.

As we began to study ruthenium(II)arene catalysts in (apparently) benign solvents, i.e. water and ionic liquids, we observed further differences in catalytic activity, with solvents able to switch on or off catalytic processes, due to activation or deactivation of key steps in the catalytic cycle. For example, ruthenium(II)-arene complexes with bis-phosphine ligands are active hydrogenation catalysts in water, ${ }^{[9]}$

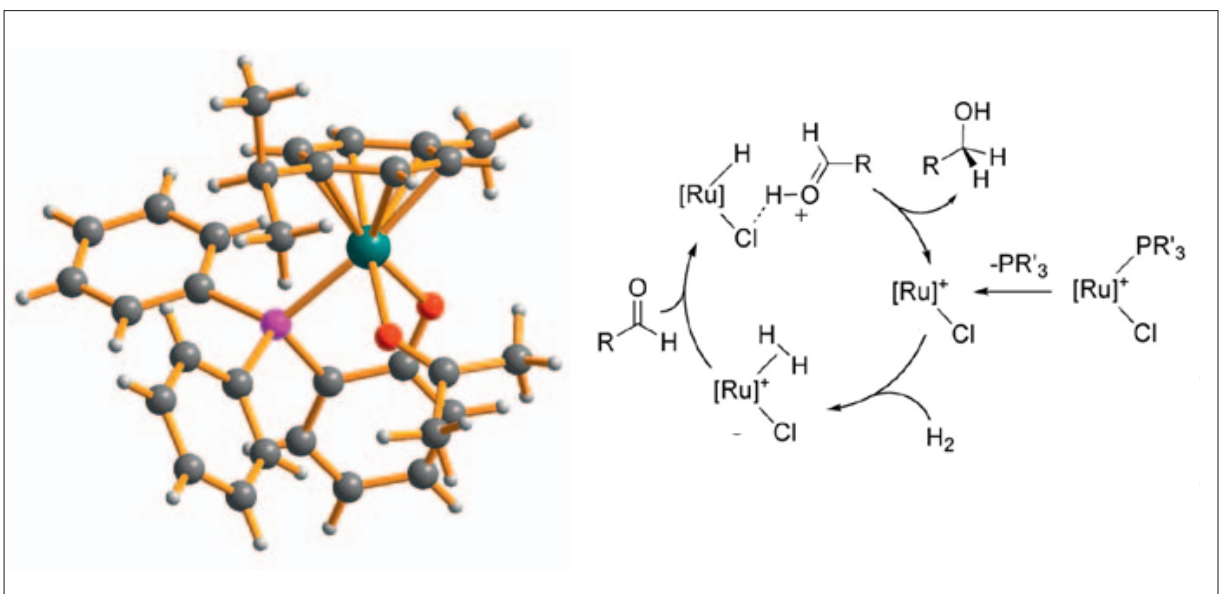

Fig. 1. Structure of $\mathrm{Ru}\left(\eta^{6}-\mathrm{p} \text {-cymene) }\left(\eta^{2}-\mathrm{PPh}_{2} \mathrm{C}_{6} \mathrm{H}_{4} \mathrm{O}\right)(\mathrm{OCMe})_{2}\right]^{+}$(left) and proposed catalytic cycle for the hydrogenation of aldehydes - note the reduction proceeds via an ionic outer-sphere mechanism (right). 


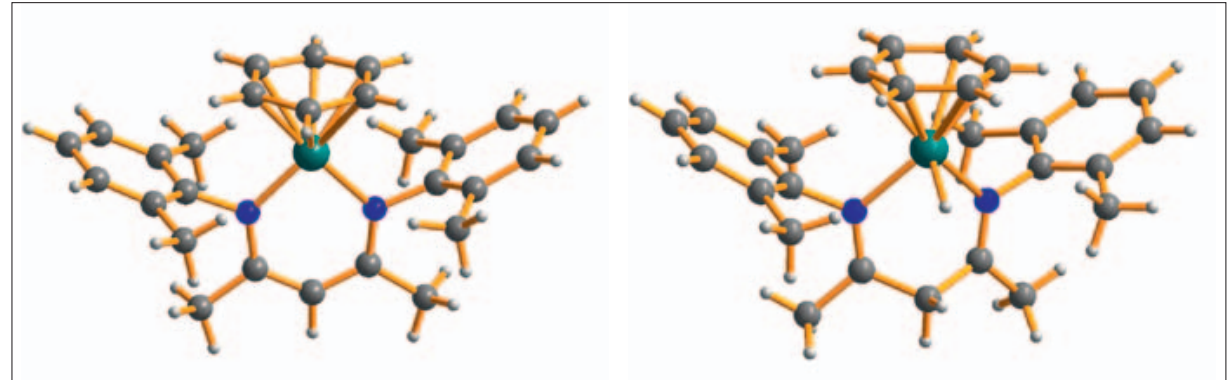

Fig. 2. Structure of $\left[\mathrm{Ru}\left(\eta^{6}-\mathrm{C}_{6} \mathrm{H}_{6}\right)\left\{(\mathrm{ArNCMe})_{2} \mathrm{CH}\right\}\right], \mathrm{Ar}=2$,6-dimethylphenyl, (left) and the product from the reaction with $\mathrm{H}_{2}$ (right).
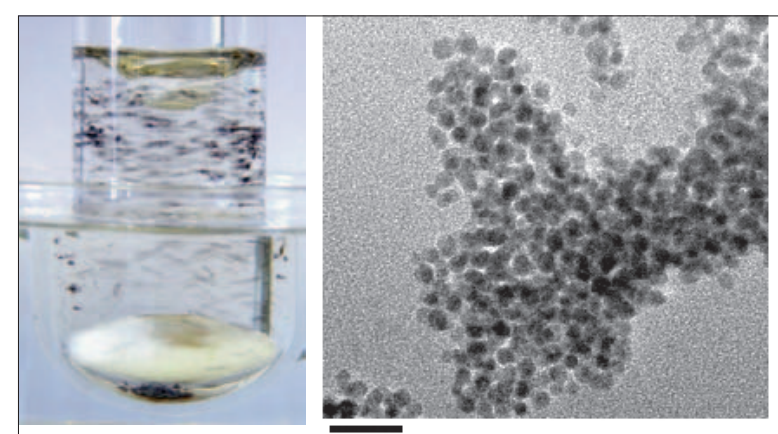

$\overline{20 \mathrm{~nm}}$



$\overline{5 \mathrm{~nm}}$

Fig. 3. A photograph of a biphasic hydrosilylation (left) and platinum nanoparticles (3-4 nm diameter) isolated from $\mathrm{PtCl}_{2}\left(\mathrm{PPh}_{3}\right)_{2}$ after five catalytic cycles in the biphasic hydrosilylation of 1-hexadecene with siloxane $\mathrm{B} 9800$ at $110^{\circ} \mathrm{C}$ in a tetrafluoroborate-based ionic liquid (centre and right). The initial catalytic activity originates from a homogeneous catalytic species.

with the active species in the hydrogenation involving a sigma-bonded dihydrogen complex. Based on a kinetic study the rate-determining step in the catalytic process involves the initial dissociation of the chloride ligand and entry of the 16-electron complex into the catalytic cycle. These catalysts were found to be essentially inactive in common ionic liquids. ${ }^{[10]}$ Inhibition of catalytic activity emphasised the problematical dissociation of the chloride anion in the ionic liquids, which was traced to the low enthalpy of solvation of chloride in ionic liquids. Although catalytic activity could be restored by a simple design strategy, the implications of this study with respect to catalysis in ionic liquids are far reaching, since many catalysts require a chloride dissociation or result in the formation of halide by-product, e.g. palladiumcatalysed cross couplings.

A thermodynamic study used to probe chloride solvation in a series of ionic liquids, ${ }^{[11]}$ showed that the reaction enthalpies are concentration-dependent, indicative of a correlated motion of the ions. For most 'simple' ionic liquids chloride ions are poorly solvated, but ionic liquids can be designed that strongly solvate chloride ions, e.g. by including a hydroxyl group on the cation. This feature was later found to play a crucial role in other catalysed reactions (see below).

Homogeneous catalysts can be modified to function efficiently in ionic liquids, ${ }^{[12]}$ although different mechanisms may operate, ${ }^{[13]}$ including the formation of nanoparticle catalysts (see Fig. 3). ${ }^{[14]}$ Indeed, the catalytic applications of nanoparticles have been extensively studied in ionic liquids, ${ }^{[15]}$ and in our own research we have taken a mechanistic approach introducing concepts used in homogeneous catalysis, i.e. catalyst improvement via rational ligand design based on steric and electronic effects of the nanoparticle stabilisers, ${ }^{[16]}$ and exploring the interplay between homogeneous (molecular) and nanoparticle catalysis. ${ }^{[17]}$

Heterogenisation of nanoparticle catalysts in ionic liquids by immobilisation on structured carbon nanofibres anchored to sintered metal fibres results in catalyst systems that display extremely high selectivities in partial hydrogenation reactions. ${ }^{[18]}$ The selectivity originates from the low solubility of the partially reduced product in the ionic liquid layer helping to eliminate it from the surface of the catalyst thereby preventing further reduction. In the production of ethylene oligomerisation (green-oil formation) was not observed and the catalyst demonstrated excellent long-term stability without any deactivation and appears to be superior to that currently used in industry.

In other reactions, notably $\mathrm{C}-\mathrm{C}$ cross couplings, we explored the role of anions and cations with respect to the in situ formation of nanoparticle catalyst reservoirs. [19]
It was found that weakly coordinating groups attached to the ionic liquid cation give rise to beneficial effects, which were analysed in terms of the interplay between the nanoparticle catalyst reservoirs, the active homogeneous catalytic species, and in some cases the formation of metal-carbene species. ${ }^{[20]}$ The nature of the ionic liquid is decisive in endowing the metal catalyst with an ideal environment that maintains high activity while sustaining stable catalytic intermediates. Moreover, ionic liquids with the right properties can transform a catalyst that is otherwise moderately active, into one that can activate unreactive $\mathrm{C}-\mathrm{Cl}$ bonds and enable sterically hindered couplings. ${ }^{21]}$ To achieve such activities it is not only necessary to consider the functionality of the ionic liquid cation, but to also control the strength of the ion pairing between the cation and anion, so as to maximise interactions between the ionic liquid and the substrates facilitating their activation. This approach was also demonstrated in the hydrodeoxygenation of lignin-derived phenols into alkanes using nanoparticle catalysts combined with Brønsted acidic ionic liquids. The system developed operates under significantly milder conditions than related processes. ${ }^{[22]}$

While ionic liquids are fascinating solvents in which to study organometallic chemistry and catalysis, perhaps the most challenging environment in which to study organometallic compounds is the cell, and much of our research is concerned with studying the function of organometallic compounds in cells in vitro and in vivo. Bioorganometallic chemistry is not a new subject, ${ }^{[23]}$ but has been of growing interesting in recent years. ${ }^{[24]}$ Our studies were initiated by the rather fortuitous discovery of a simple organometallic compounds based on a ruthenium(II) ion with an arene, phosphaadamantane (pta) and two chloride ligands, termed RAPTA compounds, that show anticancer,[25] antimetastatic ${ }^{[26]}$ and antiangiogenic ${ }^{[27]}$ effects in vivo. These compounds are remarkably selective, for example, acting on highly invasive breast cancer cells, with a lesser effect observed on normal breast cancer cells and none on healthy breast-derived cells, ${ }^{[28]}$ effectively sensitising invasive breast cancer cells towards widely applied chemotherapeutics reducing their unwanted side-effects. Since these compounds were discovered, rather than designed, their target remains elusive, however, compelling evidence that protein interactions dominate has been obtained from a series of bioanalytical studies, [29] and also from a $c a .200 \mathrm{KDa}$ structure of the nucleosome core particle, that shows binding of $\left[\mathrm{Ru}\left(\eta^{6}-p\right.\right.$-cymene $) \mathrm{Cl}_{2}$ (pta) $]$, RAPTA-C, exclusively at the histone core (Fig. 4). ${ }^{[31]}$ Such behaviour is in stark con- 


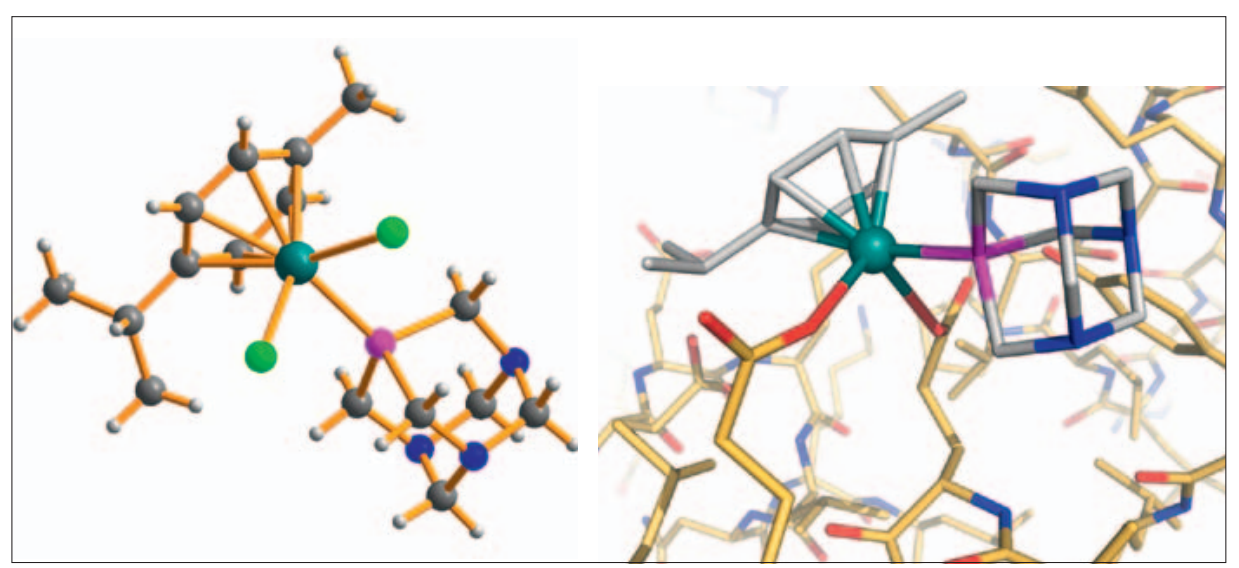

Fig. 4. Structure of (left) RAPTA-C ${ }^{[30]}$ and (right) one of the histone protein adducts formed with RAPTA-C, via substitution of the two chloride ligands, with two glutamate residues in the nucleosome core (right).

trast to cisplatin and other platinum-based drugs that bind to multiple DNA and protein sites in the nucleosome core. ${ }^{[32]}$

Modification of the basic RAPTA structure has been undertaken to explore the role of each moiety, including changing the central metal ion ${ }^{[33]}$ and modulating the rate of ligand exchange. ${ }^{[34]}$ The pta ligand has also been replaced by carbohydrate-based phosphite ligands ${ }^{[35]}$ as they are known to interfere and inhibit cell-cell recognition and adhesion phenomena, which are crucial in cancer growth and progression, ${ }^{[37]}$ and relevant to the mechanism of action of RAPTA compounds. Imidazole ligands functionalised with biologically active groups have also been introduced into the structure with very specific properties in mind - for example, to overcome certain resistance mechanisms. ${ }^{[37]}$ Modification of the arene ring presents the most interesting strategy, and as an example, the RAPTA structure was modified by attaching ethacrynic acid via cleavable and non-cleavable groups to the arene ring. ${ }^{[38]}$ Ethacrynic acid is one of the most effective inhibitors of glutathione transferases (GST), ${ }^{[39]}$ a cytosolic detoxification enzyme associated with drug resistance in primary and metastatic tumours. ${ }^{[40]}$ The lead compound from this study, $\mathrm{Ru}\left(\eta^{6}\right.$-phenyl-ethacrynate) $(\mathrm{pta}) \mathrm{Cl}_{2}$, was shown to effectively bind to GST. It induces apoptosis via a two-phase process involving an initial surge of programmed cell death followed by a more significant wave after several days. ${ }^{[41]}$ Initial binding of the compound to GSTP1-1 (the form typically over-expressed in resistant tumours) results in activation of the JNK apoptosis pathway. Subsequent release of the ruthenium fragment induces cytotoxicity via a multi-mechanism pathway and also triggers cell protection mechanisms that provide selectivity towards apoptosis-resistance cancer cells, thereby protecting healthy cells.
Strategies to target RAPTA compounds and other types of ruthenium arene compounds to tumours have been explored, including the use of serum proteins as drug carriers, ${ }^{[43]}$ attachment to dendrimer scaffolds ${ }^{[43]}$ invoking supramolecular concepts $^{[44]}$ and employing photo/thermo-activation $^{[45]}$ approaches. Nevertheless, RAPTA compounds show selectivity towards tumour tissue in vivo, and while further work is required to better understand the origin of this selectively, the most recent experiments on animal models are very encouraging.

\section{Acknowledgements} and talented group of researchers who have passed through my laboratory; their names appear in the references. A special thanks goes to the biologists, physicists and engineers who have been brave enough to venture into a world dominated by chemists. I would also like to thank Rosario Scopelliti (EPFL) and Curt Davey (NTU, Singapore) for help preparing the figures.

Received: July 1, 2011

[1] P. J. Dyson, Chimia 2005, 59, 66.

[2] P. J. Dyson, Chimia 2007, 61, 698.

[3] A. B. Chaplin, P. J. Dyson, Organometallics 2007, 26, 2447 .

[4] For example see, a) R. Noyori, H. Takaya, Acc. Chem. Res. 1990, 23, 345; b) J. H. Rigby, M. A Kondratenko, Topics Organomet. Chem. 2004, 7, 181; c) E. Bustelo, P. H. Dixneuf, Adv. Synth. Catal. 2005, 347, 393.

[5] A. B. Chaplin, P. J. Dyson, Organometallics 2007, 26, 4357 .

[6] A. D. Phillips, G. Laurenczy, R. Scopelliti, P. J. Dyson, Organometallics 2007, 26, 1120.

[7] A. Moreno, P. S. Pregosin, G. Laurenczy, A. D. Phillips, P. J. Dyson, Organometallics 2009, 28, 6432. Johnson, M. Brookhart, J. Am. Chem. Soc. 2003 , 125, 3068; b) M. C. Chen, J. A. S. Roberts, T. J. Marks, J. Am. Chem. Soc. 2004, 126, 4605; c M. Janka, W. He, A. J. Frontier, R. Eisenberg, $J$ Am. Chem. Soc. 2004, 126, 6864 .

[9] C. Daguenet R. Scopelliti, P. J. Dyson, Organometallics 2004, 23, 4849.
I am truly grateful to the highly motivated

[8] a) M. D. Leatherman, S. A. Svejda, L. K
[10] C. Daguenet, P. J. Dyson, Organometallics 2004, 23, 6080

[11] C. Daguenet, P. J. Dyson, Inorg. Chem. 2007, 46, 403. See P. Diaz, D. M. P. Mingos, R. Vilar, A. J. P. White, D. J. Williams, Inorg. Chem. 2004, 43, 7597 for the original description of the metallacage.

[12] For example see, T. J. Geldbach, P. J. Dyson, J. Am. Chem. Soc. 2004, 126, 8114.

[13] a) C. Daguenet, P. J. Dyson, Organometallics 2006, 25, 5811; b) C. Chiappe, A. Sanzone, P. J. Dyson, Green Chem. 2011, 13, 1437.

[14] T. J. Geldbach, D. Zhao, N. C. Castillo, G Laurenczy, B. Weyershausen, P. J. Dyson, J. Am. Chem. Soc. 2006, 128, 9773.

[15] For example see, a) G. S. Fonseca, A. P. Umpierre, P. F. P. Fichtner, S. R. Teixeira, J. Dupont, Chem. Eur. J. 2003, 9, 3263; b) L. S Ott, R. G. Finke, Inorg. Chem. 2006, 45, 8382; c) B. Léger, A. Denicourt-Nowicki, A. Roucoux, H. Olivier-Bourbigou, Adv. Synth. Catal. 2008. 350, 153; d) V. Calò, A. Nacci, A. Monopoli, P. Cotugno, Chem. Eur. J. 2009, 15, 1272; e) N Yan, X.-C. Xian, Y. Kou, Coordin. Chem. Rev. 2010, 254, 1179 and references cited therein.

[16] R. R. Dykeman, N. Yan, R. Scopelliti, P. J Dyson, Inorg. Chem. 2011, 50, 717

[17] a) C. Zhao, H.-Z. Wang, N. Yan, C.-X. Xiao, X.D. Mu, P. J. Dyson, Y. Kou, J. Catal. 2007, 250, 33; b) X. Yang, N. Yan, Z. Fei, R. M. CrespoQuesada, G. Laurenczy, L. Kiwi-Minsker, Y. Kou, Y. Li, P. J. Dyson, Inorg. Chem. 2008, 47, 7444 ; c) X. Yuan, N. Yan, C. Xiao, C. Li, Z. Fei, Z. Cai, Y. Kou, P. J. Dyson, Green Chem. 2010, 12, 228.

[18] a) M. Ruta, G. Laurenczy, P. J. Dyson, L. KiwiMinsker, J. Phys. Chem. C 2008, 112, 17814; b) M. Crespo-Quesada, R. R. Dykeman, G. Laurenczy, P. J. Dyson, L. Kiwi-Minsker, J. Catal. 2011, 279, 66.

[19] C. Chiappe, D. Pieraccini, D. Zhao, Z. Fei, P. J. Dyson, Adv. Synth. Catal. 2006, 348, 68.

[20] a) D. S. Reddy, D. Zhao, Z. Fei, C. M. Rao Volla, P. J. Dyson, P. Vogel, Synlett 2006, 3155; b) Z. Fei, D. Zhao, D. Pieraccini, W. H. Ang, T. J. Geldbach, R. Scopelliti, C. Chiappe, P. J. Dyson, Organometallics 2007, 26, 1588; c) X. Yang, Z. Fei, T. J. Geldbach, A. D. Phillips, C. G. Hartinger, Y. Li, P. J. Dyson, Organometallics 2008, 27, 3971; d) Y. Cui, I. Biondi, M. Chaubey, X. Yang, Z. Fei, R. Scopelliti, C. G. Hartinger, Y. Li, C. Chiappe, P. J. Dyson, Phys. Chem. Chem. Phys. 2010, 12, 1834.

[21] N. Yan, X. Yang, Z. Fei, Y. Li, Y. Kou, P. J. Dyson, Organometallics 2009, 28, 937.

[22] N. Yan, Y. Yuan, R. Dykeman, Y. Kou, P. J. Dyson, Angew. Chem. Int. Ed. 2010, 49, 5549.

[23] 'Bioorganometallics', Ed. G. Jaouen, Wiley$\mathrm{VCH}$, Weinheim, 2006.

[24] C. G. Hartinger, P. J. Dyson, Chem. Soc. Rev. 2009, 38, 391.

[25] S. Chatterjee, S. Kundu, A. Bhattacharyya, C. G. Hartinger, P. J. Dyson, J. Biol. Inorg. Chem. 2008, 13, 1149 .

[26] C. Scolaro, A. Bergamo, L. Brescacin, R. Delfino, M. Cocchietto, G. Laurenczy, T. J. Geldbach, G. Sava, P. J. Dyson, J. Med. Chem. $\mathbf{2 0 0 5}, 48,4161$

[27] P. Nowak-Sliwinska, J. R. van Beijnum, A. Casini, A. Nazarov, G. Wagnières, H. van den Bergh, P. J. Dyson, A. W. Griffioen, J. Med. Chem. 2011, 54, 3895.

[28] A. Bergamo, A. Masi, P. J. Dyson, G. Sava, Int. J. Onco. 2008, 33, 1281.

[29] A. Casini, C. H. Hartinger, A. A. Nazarov, P. J. Dyson, Top. Organomet. Chem. 2010, 32, 57.

[30] C. S. Allardyce, P. J. Dyson, D. J. Ellis, S. L. Heath, Chem. Commun. 2001, 1396.

[31] B. Wu, M. S. Ong, M. Groessl, Z. Adhireksan, C. G. Hartinger, P. J. Dyson, C. A. Davey, Chem. Eur. J. 2011, 17, 3562. 
[32] B. Wu, P. Droge, C. A. Davey, Nature Chem. Biol. 2008, 4, 110 .

[33] a) A. Dorcier, P. J. Dyson, C. Gossens, U. Rothlisberger, R. Scopelliti, I. Tavernelli, Organometallics 2005, 24, 2114; b) A. Dorcier, C. G. Hartinger, R. Scopelliti, R. H. Fish, B. K Keppler, P. J. Dyson, J. Inorg. Biochem. 2008, $102,1066$.

[34] a) W. H. Ang, E. Daldini, C. Scolaro, R. Scopelliti, L. Juillerat-Jeannerat, P. J. Dyson, Inorg. Chem. 2006, 45, 9006; b) A. Ratanaphan, P. Temboot, P. J. Dyson, Chem. Biodiversity 2010, 7, 1290.

[35] a) I. Berger, M. Hanif, A. A. Nazarov, C. G. Hartinger, R. John, M. L. Kuznetsov, M. Groessl, F. Schmitt, O. Zava, F. Biba, V. B Arion, M. Galanski, M. A. Jakupec, L. JuilleratJeanneret, P. J. Dyson, B. K. Keppler, Chem. Eur. J. 2008, 14, 9046; b) M. Hanif, S. M. Meier, W. Kandioller, A. Bytzek, M. Hejl, C. G. Hartinger, A. A. Nazarov, V. B. Arion, M. A Jakupec, P. J. Dyson, B. K. Keppler, J. Inorg. Biochem. 2011, 105, 224.

[36] P. Nangia-Makker, J. Conklin, V. Hogan, A Raz, Trends Mol. Med. 2002, 8, 187.

[37] a) C. A. Vock, W. H. Ang, C. Scolaro, A. D. Phillips, L. Lagopoulos, L. Juillerat-Jeanneret, G. Sava, R. Scopelliti, P. J. Dyson, J. Med. Chem. 2007, 50, 2166; b) W. H. Ang, A. De Luca, C. Chapuis-Bernasconi, L. Juillerat-Jeanneret, M. Lo Bello, P. J. Dyson, ChemMedChem. 2007, 2 1799.
[38] W. H. Ang, L. J. Parker, A. De Luca, L. Juillerat-Jeanneret, C. J. Morton, M. Lo Bello, M. W. Parker, P. J. Dyson, Angew. Chem. Int. Ed. 2009, 48, 3854

[39] H. W. Lo, F. Ali-Osman, Curr. Opin. Pharmacol. 2007, 7, 367.

[40] J. D. Hayes, J. U. Flanagan, I. R. Jowsey, Ann. Rev. Pharmacol. Toxicol. 2005, 45, 51 .

[41] S. Chatterjee, I. Biondi, P. J. Dyson, A. Bhattacharyya, J. Biol. Inorg. Chem. 2011, 16, 715 .

[42] W. H. Ang, E. Daldini, L. Juillerat-Jeannerat, Paul J. Dyson, Inorg. Chem. 2007, 46, 9048

[43] a) P. Govender, N. C. Antonels, J. Mattsson, A. K. Renfrew, P. J. Dyson, J. R. Moss, B. Therrien, G. S. Smith, J. Organomet. Chem. 2009, 694, 3470 ; b) P. Govender, A. K. Renfrew, C. M. Clavel, P. J. Dyson, B. Therrien, G. S. Smith, Dalton Trans. 2011, 40, 1158.

[44] A. Pitto-Barry, N. P.E. Barry, O. Zava, R. Deschenaux, P. J. Dyson, B. Therrien, Chem. Eur. J. 2011, 17, 1966.

[45] a) F. Schmitt, P. Govindaswamy, G. Süss-Fink, W. H. Ang, P. J. Dyson, L. Juillerat-Jeanneret, B. Therrien, J. Med. Chem. 2008, 51, 1811; b) A. K. Renfrew, R. Scopelliti, P. J. Dyson, Inorg. Chem. 2010, 49, 2239. 